\title{
ANALYSIS OF THE MARKET OF ITALIAN TOURIST SERVICES AS A FACTOR OF SOCIAL AND ECONOMIC DEVELOPMENT BEFORE AND DURING THE COVID-19 PANDEMIC
}

Tereshchuk Oksana, Candidate of Geographical Sciences, Associate Professor of Tourism and Hospitality, Lesya Ukrainka Volyn National University, Lutsk, Ukraine

e-mail: t.oksana777@gmail.com

ORCID ID https://orcid.org/0000-0001-8131-1270

Lysiuk Tetiana, Candidate of Geographical Sciences, Associate Professor of Tourism and Hospitality, Lesya Ukrainka Volyn National University, Lutsk, Ukraine

e-mail: tetiana.0602@gmail.com

ORCID ID https://orcid.org/0000-0003-1629-9652

Drobetska Vlada, 5 year Student of the Faculty of Geography, Lesya Ukrainka Volyn National University, Lutsk, Ukraine e-mail: drobetska_vlada@ukr.net

ORCID ID https://orcid.org/0000-0002-4390-4777

Анотація. Purpose. The purpose of this study is to analyze the current issue, namely the situation in the Italian tourism industry, as a lever for the development of society and economy before and during the COVID-19 pandemic and the leader among European countries in tourism development. Method. This article uses the methods of analysis, synthesis, comparison and systematization to make theoretical generalizations. Use the logical generalization method and the systematic method to draw conclusions. Results. The article found that due to the spread of the coronavirus, the Italian tourism industry is facing what may be the most serious crisis in the history of the world economy. It is said that during the pandemic caused by COVID-19, it was tourism that suffered the most, due to limited measures inviting the state to relocate citizens, quarantine, and ban the air transportation of others.

Practical importance. Practical suggestions to solve the crisis and put them into practice will reduce the negative impact of the pandemic on the Italian economy and tourism economy.

Ключові слова: tourism; tourism industry; business; economy; crisis; COVID-19.

\section{АНАЛІЗ РИНКУ ТУРИСТИЧНИХ ПОСЛУГ ІТАЛІЇ ЯК ФАКТОР РОЗВИТКУ СУСПІЛЬСТВА ТА ЕКОНОМІКИ ДО ТА ПІД ЧАС ПАНДЕМІЇ COVID-19}

Терещук О. С., кандидат географічних наук, доцент кафедри туризму та готельного господарства, Волинський національний університет імені Лесі Українки, м. Луцьк, Україна

e-mail: t.oksana777@gmail.com

ORCID ID https://orcid.org/0000-0001-8131-1270

Лисюк Т. В., кандидат географічних наук, доцент кафедри туризму та готельного господарства, Волинський національний університет імені Лесі Українки, м. Луцьк, Україна

e-mail: tetiana.0602@gmail.com

ORCID ID https://orcid.org/0000-0003-1629-9652

Дробецька В. С., студент 5 курсу географічного факультету, Волинський національний університет імені Лесі Українки, м. Луцьк, Україна

e-mail: drobetska_vlada@ukr.net

ORCID ID https://orcid.org/0000-0002-4390-4777

\begin{abstract}
. ТМета. Метою даного дослідження є аналіз поточної проблеми, а саме ситуачї в італійській туристичній галузі, як важеля розвитку суспільства та економіки до та під час пандемії COVID-19 та лідера серед європейських країн у розвитку туризму. Методика. У статті використано методи теоретичного узагальнення із використанням елементів аналізу, синтезу, порівняння і систематизачії. Для формування висновків застосовано метод логічного узагальнення та системного підходу. Результати. У статті з'ясовано, щуо у зв'язку із поширенням коронавірусу туристична індустрія Італії постала перед кризою, яка може виявитися найгіршою в історії світової економіки. Указано, шо під час пандемії, спричиненої COVID-19, саме туризм постраждав найбільше, зокрема через обмежувальні заходи, які запроваджують
\end{abstract}


держави на пересування громадян, карантин, заборону авіаперевезень тощьо. Тому, оцінивщи сьогоднішній стан туризму, з'ясовано, шуо іноземні потоки в країну постраждали найбільще, адже Італія значною мірою залежить від Європи, з якої надходить 79\% туристів. Загальний обсяг перевезень в країні порівняно з аналогічним періодом 2019 року, впав на 93\%, шуо є одним із найгірших результатів на континенті за даними Свроконтролю. Особливого краху зазнали круїзи, а розміщуення та туризм ризикують втратити 30-35\% обороту за базовим сиенарієм та 60-70\% за песимістичним, изо ми бачимо на січень місяць 2021 року. Наукова новизна. Наукова новизна дослідження полягає у тому, щзо у статті виявлено вплив та підсумовано наслідки пандемії COVID-19 для туристичної економіки Італії як провідної туристичної країни Свропи, яка триває до ичього моменту, і сформовано перелік заходів для якомога швидшого відновлення туристичних потоків до та з країни, для подальшого відновлення національної економіки загалом. Практична значимість. Надано практичні рекомендації щуодо поступового виходу з кризи, упровадження яких дасть змогу змениити рівень негативного впливу наслідків пандемї на економіку туристичної галузі Італії.

Kеуwords: туризм; туристична індустрія; бізнес; пандемія; економіка; криза, COVID-19.

JEL Classification: Z320

Formulation of the problem. The scale of the COVID-19 pandemic has led the world scientific community to acknowledge that they were unprepared for such a rapid and active development of the disease when a UNWTO press release of March 6, 2020 estimated that the pandemic would reduce the number of tourists by 1-3\% (compared to 2019), rather than the projected growth of $3-4 \%$. Three weeks later, on March 26, a press release updated this estimate to $20-30 \%$ of losses on international arrivals.

The pandemic has caused one of the main problems of today, especially for the service sector and tourism, precisely because of its unpreparedness for it. Italy, as one of the leaders in tourism arrivals in Europe, where tourism as a sector of the economy accounted for $13 \%$ of GDP in 2019, was one of the first to face the impact of the pandemic and suffered devastating consequences that returned the country's tourism to the 1990s. Italy's tourism resumption time can take 3 to 5 years. But the Italian government, like other countries, world tourism communities, tourism organizations, scientists, local governments and ordinary citizens, is looking for a way out of today's situation, which has put tourism in decline, to get out of the pandemic as soon as possible with minimal consequences for the industry. Society and the economy as a whole. And the pandemic itself, caused by the SARS-CoV-2 virus, is forcing the Italian government to look at the development of tourism in a different way, given the further development of the tourism industry in the country.

Analysis of recent research and publications. To date, a large number of scientists have conducted a number of studies of the tourism business in crisis circumstances, because it requires a systematic scientific analysis of various components of tourism, generalization of world and national experience in overcoming crises, namely the following leading domestic scientists in tourism: I. Smal, O. Beidyk, T. Tkachenko, M. Malska and foreign scientists - Gozgor and Ongan (2017), Demir and Ersan (2018), Sharma (2019), Uzuner, Chisadza (2020), as well as the study is based on analytical, statistical materials UNWTO, WTTC.

Separation of previously unsolved parts of the overall problem. Unsolved previous parts of the problem are the indicators of the functioning of the Italian tourism industry in recent years and their comparison with indicators during the SARS-CoV-2 virus: cooperation and the importance of tourism as a sector of the economy in the country's GDP; number of external and internal tourist flows; the main tourist and recreational base of Italy; conjuncture of the local tourist market, its orientation on the international arena.

The aim of the study. The purpose of this study is to analyze the current issue, namely the situation in the Italian tourism industry, as a lever for the development of society and economy before and during the COVID-19 pandemic and the leader among European countries in tourism development.

Presenting main material. Reaching the 21 st century, mankind has established a mechanism for travel to all countries of the world, because now they are closely connected with each other. Tourism has become one of the most dynamic sectors of the world economy. Today it is an important area of socio-economic life of many countries and regions of the world. The modern tourism industry occupies an important place in international economic relations and influences the development of the economy of individual countries and the world economy as a whole.

For some countries, tourism is key in the economy. For Italy, tourism is one of the most important economic sectors, an important factor in the export potential of the Italian economy, an important area of employment, a source long-term development, tourism in Italy, in 2019, accounts for $13 \%$ of the country's GDP.

International demand for Italy as a tourist destination has been and remains very high. Over 
the last century of development of the Italian tourism industry, the country has become one of the leading tourism centers in the world. In 2019, before the COVID-19 pandemic, more than 36\% of tourist visits to the Mediterranean basin were in Italy.

The last decade has marked a clear trend: domestic tourism has been severely affected by the economic crisis, so much so that flows have been steadily declining from 2008 to 2014 and only recovering from 2015; on the other hand, inbound tourism showed a much better trend with growth and stable rates so much that it recorded $+34 \%$ in 2008 . These data clearly illustrate the importance of the international sector to Italy now: since 2017, foreigners have accounted for more than $50 \%(50.5 \%)$ of the total number of tourists. [3].

Revenues from tourism in Italy, due to the rapid spread of COVID-19 worldwide, in January 2021 decreased to 413 million euros, for comparison, in January 2019, revenues from tourism in Italy amounted to 2180 million euros; and at the peak of the tourist season - July 2020 , revenues from tourism amounted to 3275 million euros, and the same month in 2018 amounted to 5478 million euros, and the peak fell in 2019, when revenues from tourism reached 6023 million euros. (figure 1.1).

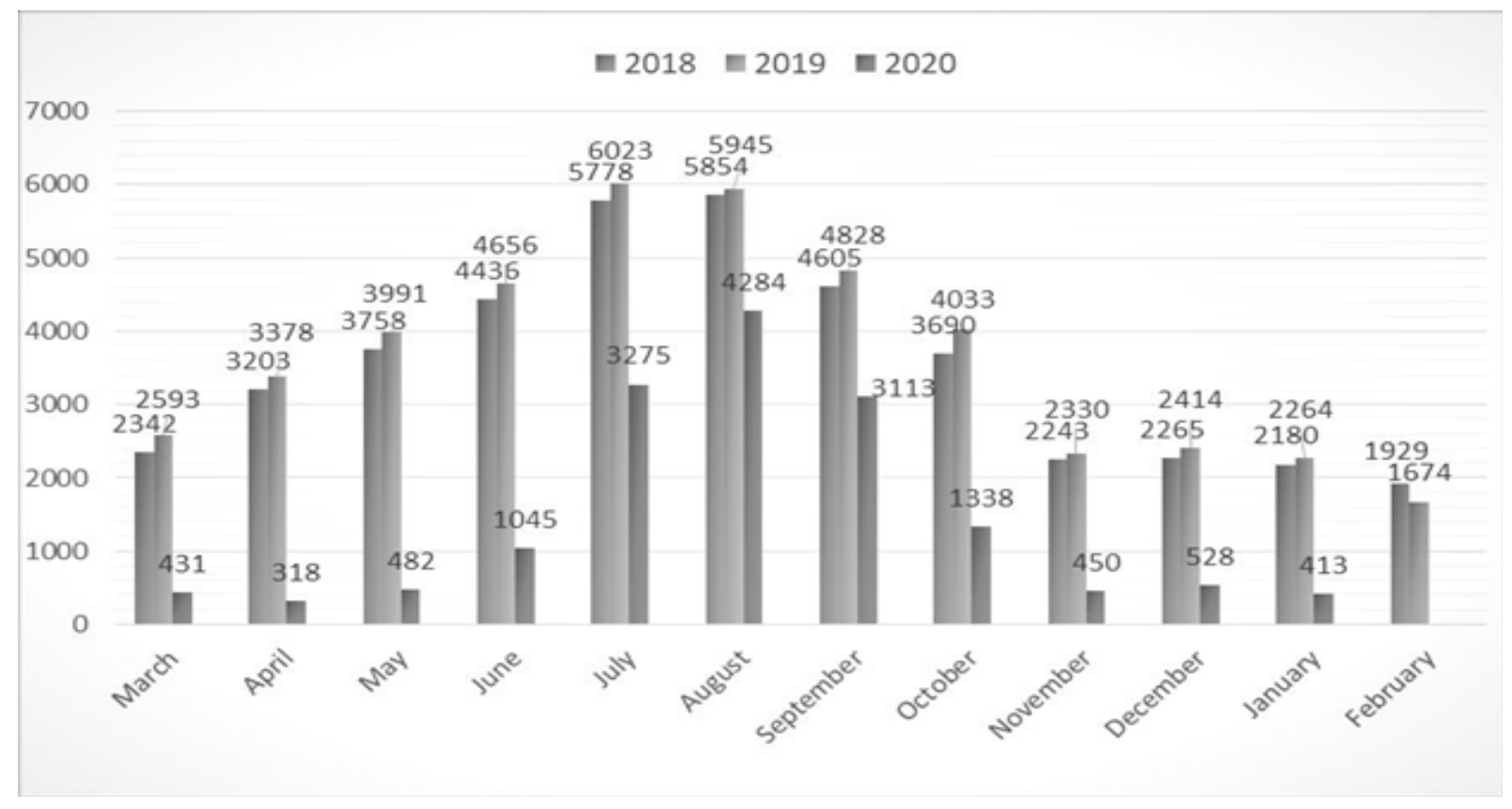

Source: Tradingeconomics.com/Banca D'Italia 2020. Figure 1.1. Revenues from tourism in Italy from 2018-2021, (million euros)

Hence, the tourist industry of Italy in general is a complex system, which includes the actual tourist product (service, tour); consumers of tourist products and related services; objects of the tourist industry - companies that create and distribute the tour product (tour operators, travel agents), institutions and enterprises that provide accommodation, food, transportation; state bodies of management of tourist branch, educational and scientific establishments. In addition, with the development and complexity of the tourism organization process, matters involving trading companies, insurance companies, banks, and communication companies are also involved.

Typical related subjects of the Italian tourism industry are advertising and information companies, visa organizations, souvenir businesses, sporting goods and leisure goods, entertainment industry, companies selling tourist clothing, photography, etc. [5]. An important role in the development of international tourism in the country is played by the National Tourism Administration, which has a wide network of offices abroad. In some countries, it operates through the state-owned airline Alitalia and other firms. This department studies the situation in the international tourism market, conducting advertising campaigns and increasing the flow of tourists from abroad to the country. International tourism in Italy is an industry that unites a significant number of enterprises, institutions, and organizations of the world economy, has a multibillion-dollar annual turnover and for some countries is the main area of economic activity. The economy of the highly developed countries of the world to some extent depends on tourism. In Italy, revenues from foreign tourism increase the balance of payments by $120-130 \%$. 
If we analyze the tourist and recreational resources, Italy has a rich high-quality natural and cultural-historical resources with a predominance of mountains, lakes and cultural values, which are concentrated in the north and widely known worldwide, as evidenced by the largest number of World Heritage sites. UNESCO constitutes a unique base for the development of tourism.

There are 49 sites in the country ( 45 cultural and 4 natural), which are included in the World Heritage List, which has a total of 981 sites. There are 24 national parks, numerous regional parks, marine areas, state reservoirs and wetlands in Italy. Various protected areas make up 10\% of the country's area and their number is constantly growing, which contributes to the preservation of natural heritage [6].

Italian cities have world-famous tourist centers. Many of them have existed since ancient Rome, were the capitals of medieval principalities and are now a treasure trove of works of art, historical and architectural monuments. Amongst them are Bologna, Padua, Parma, Pisa, Ravenna and many others. The main area of foreign tourism is the northeast, especially the regions of Trentino-Alto Adige and Veneto, as well as Central Italy (Rome, Florence, Venice). The capital of Italy, Rome, is one of the most visited cities in the world (7-10 million tourists a year), and the Roman Colosseum with 4 million visitors a year is the most visited a tourist destination in the world. Religious tourism also thrives here, thanks to the Vatican's location within Rome.

It is worth mentioning that one of the main branches of the tourism industry is the hotel industry or hotel industry. At the end of the 20th century, the European Community began to implement a costly project to develop tourism infrastructure in Medjogiorno, southern Italy, at a total cost of 34.9 million Euros. This fact, in turn, contributed to the creation of 65 thousand additional hotel rooms. In Italy, hotels are divided into categories determined by the number of stars: from one to five "luxury" stars. Other tourist accommodation establishments create a network of additional facilities, including campsites, tourist villages, holiday homes, youth homes, private apartments, alpine shelters, and more.

The most famous hotel chains and businesses in Italy: Intercontinental De La Ville Rome (Intercontinental Hotels \& Resorts chain), St. George, Grand Hotel De La Minerve (Worldhotels hotel chain), The Gray (Sina Hotels hotel chain), The Westin Palace (Westin hotel chain).

Nearly 60 million tourists stay in all accommodation facilities in Italy every year, and usually $35 \%$ of them are foreigners. Most hotels in the country are concentrated in the Northeast. Italy offers accommodation both for demanding tourists who prefer full-time and luxury vacations with a full range of services, and for the economy tourism, which is unpretentious to the accommodation, and more price-orientated. If we take into account 2018, which can safely be called the year of the peak of tourism in Italy, the tourism authorities in Italy recorded 429 million bookings (nights) in official structures (hotels and non-hotels) with a growing trend, albeit restrained, from 2010 to the present [3].

The main suppliers of tourists to Italy are: Germany, France, Austria and Switzerland, rarely from the United States. Tourists from Germany occupy leading positions not only in number but also in length of stay. In 2018, Italy was one of the five European countries in terms of the number of foreign tourists with an attendance of 34.1 million [7]. And the Italians themselves prefer European countries, especially France. Demand for travel to North America, Asia and the Caribbean has recently increased. As a result of a significant increase in outbound tourism, Italy is now ranked 5th in the world in the cost of tourists abroad. Compared to other leading European countries in tourism, Italy is considered a younger destination, but the huge influx of tourists already has negative consequences for the country. Many beaches are polluted, there is a threat to the preservation of works of art.

The tourist product offered by Italy is owing to the presence of the above-mentioned rich resources, the country has a favorable geographical position at the crossroads of trade routes between West and East, where the mountainous terrain - the Alps and the Apennines. The Aosta Valley is sandwiched in the northwestern corner of Italy, bordering France, Switzerland, and the Piedmont region. This region - known for its natural landscape - is ideal for nature travelers. This contributed to the development of fashionable ski resorts, which in their popularity among tourists are not inferior to the Austrian and Swiss, attract fans of climbing, caving, rafting. The most popular are Val Gardena, Val di Fassa, Alta Badia, Arabba and others.

Lombardy is a Lake District in Italy, located in northern Italy. The region is known for its metropolitan atmosphere and incomparable lake district. It borders Switzerland and the Italian regions of Piedmont, Liguria, Emilia Romagna, Veneto and Trentino-Alto Adige, and Lombardy is the epicenter of nightlife, fashion, business and international affairs.

Milan - the Fashion Center of the world and the second largest city in Italy - is the capital of 
the region and invites travelers to look into the cosmopolitan world, which is modern Italy.

Veneto Bordering Austria and four regions of Italy - Trentino-Alto Adige, Lombardy, EmiliaRomagna and Friuli-Venezia Giulia - Veneto offers sea and mountain landscapes, as well as art, architecture and fine wine. As one of the most developed regions of Italy, Veneto attracts more than 50 million tourists every year.

In the central part of Italy is the natural paradise of Abruzzo, which boasts everything from mountains to beaches to the vast countryside. Bordering the Marche, Lazio, Molise and the Adriatic Sea.

The Mediterranean climate, the presence of the Adriatic (in the east), Ionian (in the south), Mediterranean, Tyrrhenian and Ligurian (in the west) seas, a number of islands create the conditions for the successful development of beach tourism. The small islands of the Gulf of Naples, Capri and Ischia, live almost exclusively through tourism. Amongst the most famous and visited seaside resorts are Lido di Jesolo, Lignano, San Remo, Costa Viola, Amalfi, Maiori, Minori, Sorrento, Salerno and others. Medical tourism has become popular among tourists. Among the thermal resorts the most popular are Abano Terme, Cortina d'Ampezzo, Terme di Petriola, Montegrotto Terme, Ischia, Bormio and others. Ecotourism centers: Gran Paradiso, Stelvio, Circeo, Abruzzo $[1]$.

It is worth mentioning the cooperation of Italy with Ukraine. Italy recognized Ukraine's independence on December 28, 1991, and diplomatic relations between the two countries were established on January 29, 1992. In 1993, Ukraine opened the Embassy of Ukraine in Italy in Rome. The Italian Embassy in Ukraine was opened by Italy in Kyiv. Since the establishment of diplomatic relations between Italy and Ukraine, there have been several visits by the President of Ukraine to Italy: in May 1995, November 2002, October 2008, November 2015 and February 2020. The leading role in representing Italy in the international tourism market belongs to the National management of tourism (Ente Nazionale Italiano a Il Turismo - ENIT), the main functions of which are advertising and information work, marketing research, coordination of international activities of local tourist administrations. If we draw a parallel cooperation between Italy and Ukraine, Ukraine is interested in learning from the experience of ENIT on the development of certain areas and regional aspects of national tourism in some provinces of Italy, presentation of tourism products in major provinces at international tourism salons and establishing cooperation between government and private tourism enterprises.

The year 2020 was marked by a deep and large-scale pandemic for the whole world, which radically affected not only Italian tourism, but also the world as a whole, virtually suspending it.

Assessing the tourist process in Italy, it is worth stopping and considering in more detail the current state of tourism in the country. Describing foreign flows in more detail, Italy is heavily dependent on Europe, which accounts for 79\%. Flows in Europe (final estimate in 2019), of which more than half $(54 \%)$ is due to the attractiveness of the regions of Northern Italy, have suffered the most from the COVID-19. Looking at the monthly travel flows, of course, the "hottest" periods for Italian tourism are the summer quarters (June-August), which account for about $50 \%$ of the total attendance per year. Given only the domestic market, the concentration of summer is even stronger, while flows between January and April bring the average monthly share of $5 \%$ to the total for the year (therefore, quite low) [3].

As for foreigners, the seasonal curve is slightly flatter in summer (about $45 \%$ of the total) than in the domestic market, and peaks in July (instead of August). The losses suffered by the tourism industry in Italy are large. With regard to air transport, a key sector for Italian tourism, in particular for long-distance transport, in the fourteenth week of 2020 (from March 30 to April 5) the total volume of traffic in the country compared to the same period in 2019 fell by $93 \%$, which is one of the worst results on the continent according to Eurocontrol. This inevitable reduction in air and passenger traffic will have a direct impact on foreign tourism costs in Italy, in particular for those markets that could not reach Italy in any other way than by plane. Today, about 45 billion euros spent by foreigners in Italy, one third of non-European travelers: according to Eurocontrol, if the emergency with the coronavirus lasts a long time, in 2020, the country risks laying about $30 \%$ of entry costs to Italy without taking to account for changes in the behavior of other foreign tourists in the middle range, almost all of German, which, as noted above, now account for more than a quarter of incoming tourists [3].

The flight segments that have been particularly affected by the disaster will be hit harder by the already worsening crisis. Today, the sector is significant: approximately 32 million berths are available daily on cruise ships worldwide, of which $28 \%$ are in the Euro-Mediterranean area, second only to the Caribbean (34\%). In addition, in terms of demand, they are one of the most successful 
products of recent decades: in 2019, about 30 million passengers were transported, an increase of almost $250 \%$ compared to 1999 , when there were less than 9 million cruise passengers. In the Mediterranean region, Italy plays a central role: among the 20 main ports for passenger traffic, eight - Italian (in order of relevance: Civitavecchia, Venice, Naples, Genoa, Savona, Livorno, Palermo and Bari). Civitavecchia, with 2.4 million passengers a year, is the second Mediterranean port after Barcelona.

The impact on culture and trade is the same. Let us not forget that by definition, tourism is an industry originally composed of housing, food, and transportation, which directly affects the entire culture and trade. For 100 euros spent by Italian and foreign tourists in Italy, more than a third goes to hospitality, 13 euros - to catering, 12 - to trade (for shopping), 7 - to air transportation, about 6 to other modes of transport ( rail, sea, road), 4 to intermediary (travel agencies and tour operators) and more than 3 to cultural, sports and recreational services, 20 euros for other services that are not among the main and most important (insurance, general expenses or services) [3]. Thus, tourism has an impact that extends to many sectors of the Italian economy, which due to coronavirus may have a strong travel and holiday crisis, blocking the demand for small businesses such as tourism (according to UNWTO 80\% are small and medium enterprises) risks becoming fatal, as activities that traditionally do not have great financial opportunities, for a long time withstand a sudden lack of demand, accommodation and tourism risk losing 30-35\% of turnover in the baseline scenario and $60-70 \%$ in the pessimistic, which we see for the month of January 2021.

Then, in the near future, when the coronavirus will finally be defeated or at least under control, two goals will be outlined - on the one hand, "rescue," which the government is already working on at the moment to support business and prevent its closure, considering the blockade. The Italian system; on the other - "recovery". The government of the country faces many questions on how to coordinate the work of tourism authorities so as to return the indicators of 2018-2019 as soon as possible. Although it is now difficult to predict how and when the basic mechanisms of tourism will be restarted, we can still hypothesize some elements of the scenario that may characterize the restart phase of Italian tourism:

1. Health issues will be central, which means that it will probably be easier to travel to areas where the system does not pose a risk of infection and will be prepared to respond to emergencies or new possible outbreaks of the virus.

2. The so-called stay or localization restriction will be established.

3. Outbound tourism will dominate domestic tourism, which will contribute to less overcrowding in Italy, outdoor activities and relaxation tourism.

4. Individual trips (for couples and families) will resume faster, especially in the beginning, before group trips due to the probable need (or predisposition) it is necessary to maintain forms of social distancing.

5. The Internet will remain the main tool for booking tours under the influence of a pandemic.

6. Possible change in the seasonality of certain resorts.

7. It is likely that in the initial stages of tourism in Italy will be "poorer" and shorter than the terms of tourism in 2018-2019.

8. The recovery period is a fundamentally important issue: the faster it is, the lower will be the minimized risk of bankruptcy of companies in this sector, and the crisis can fuel organized crime [3].

Conclusion. Italy needs to adapt the supply of the national tourism product to the needs and demands of the changing and dynamic modern market and to create a favorable environment for tourism development. An important part of such an environment is new information technologies, in particular, the World Wide Web, which has radically changed the international tourism industry in 2020 .

No less important problems that hinder the development of the tourism sector are the fragmentation and localization of Italy's tourism business by region due to the lack of effective centralized coordination; difficulties in attracting international investment, inability (and unwillingness) to develop new tourism offers; insufficient infrastructure; lack of well-trained staff; primarily due to a poorly established administrative system and excessive bureaucratization of the process.

For the rapid and effective restoration and development of tourism in Italy should equally promote all aspects of tourism development, namely: management, communications and promotion, sales channels, product range, hospitality, transport and infrastructure, training and skills, investment, regulatory framework.

Tourism experts are afraid to provide information on the prospects for further development of tourism, so now Italy and the world have to do everything possible to support what has accumulated 
in previous years and not allow the pandemic to destroy tourism as an industry.

\section{References}

1. Alexandrova A.Y. (2002). International tourism. M.: [b.i.]. [in Ukrainian].

2. Afanasenko I.D. (1995). Tourism and economic reform. Proceedings of the Academy of Tourism, 1, 53-67. [in Ukrainian].

3. Coronavirus: what are the conditions for tourism in Italy? Retrieved from: https://www. touringclub.it/.

4. Sakaeva L.R., Bazarova L.V. (2014). The concepts of "tourism" and "tourist discourse" in the modern scientific paradigm. Philological sciences. Questions of theory and practice, 6 (36): in 2 parts Part I., 159-161. [in Ukrainian].

5. Shyka. G.P. (2010). Tourist characteristics of Italy. Geography and Tourism. (6-x ed.), 122-125. [in Ukrainian].

6. Smal I.V. (2010). Tourist resources of the world . Nizhyn: Nizhyn Publishing House. State Mykola Gogol University. [in Ukrainian].

7. Statistical Office of the European Union (2019), "Dynamics of tourist flows for the purpose of recreation and rest", Retrieved from https://ec.europa.eu/eurostat.

\section{Список літератури}

1. Александрова А. Ю. Международный туризм. М.: [б.и.], 2002. 337.

2. Афанасенко И. Д. Туризм и реформирование экономики. Труды Академии туризма. 1995. № 1. 53-67 c.

3. Coronavirus: quali le conseguenze per il turismo in Italia? URL: https://www.touringclub. it/.

4. Сакаева Л. Р., Базарова Л. В. Понятия «туризм» и «туристический дискурс» в современной научной парадигме. Филологические науки. Вопросы теории и практики. 2014. № 6 (36).В 2-х ч. Ч. І. С. 159-161.

5. Щука Г. П. Туристська характеристика Італії. Географія та туризм. 2010. Вип. 6. С. 122-125.

6. Смаль І.В. (2010). Туристичні ресурси світу. Ніжин : Вид-во Ніжин. держ. ун-у імені Миколи Гоголя, 2010. 336 c.

7. Statistical Office of the European Union (2019), "Dynamics of tourist flows for the purpose of recreation and rest". URL: https://ec.europa.eu/eurostat. 